\title{
Fostering Sustainability in New Value Chains for (Re)Adopting Underutilized Crops
}

\author{
Araceli Bjarklev ${ }^{1}$, Bente Kjærgård ${ }^{1}$, Erling Jelsøe ${ }^{1}$ and Henrik Haugaard-Nielsen ${ }^{1}$
}

\begin{abstract}
In the European Union, diversification into more resilient crops and the massive deficit in protein production constitute a huge challenge. Among recommended food alternatives to help solve this problem are high-value ancient underutilized agricultural crops recommended by international institutions, which are usually more resilient than mainstream crops and often have higher protein content. Our hypothesis is that there is a need for a more holistic framework that encompasses most of the issues to be considered when developing sustainable value chains for (re)adopting underutilized crops. To test our hypothesis and suggest a more holistic approach, we conducted a review of existing scientific literature in the field. Here, we identify the most relevant issues suggested as preconditions for (re)adopting underutilized crops. We discuss the theoretical background of the main constraints or drivers and their effect on the realization of more socially, environmentally and financially sustainable adoption strategies. As a result, the study suggests a more holistic framework.
\end{abstract}

Key words: underutilized crops, adoption, value chain, bolistic approach, sustainable development, innovation drivers.

\section{Introduction}

Different international organizations are working towards solving the world's food demand and the impact of current food production on sustainable development. The United Nations 2030 agenda, for example, seeks to end hunger, achieve food security, improve nutrition and promote sustainable agriculture, as pointed out in the second UN Sustainable Development Goal (United Nations, 2015). Priority objectives of the European Commission, in relation to the UN's second goal, are to solve its huge protein deficit and low biodiversity and foster sustainable value chains when adopting alternative and more resilient crops. More specifically, the European Common Agricultural Policy is seeking to enhance biodiversity, knowledge transfer and innovation (European Commission, 2015) (European Commission, 2013). The EU Food 2030 strategy outlines priorities such as developing food systems that are resilient to climate and global change and solving the huge EU protein deficit (European Commission, 2015) (Maggio et al., 2016) (Hausling, 2011).

According to the Food and Agricultural Organization (FAO): "The underutilized food resources have a much higher nutrient content than globally known species or varieties commonly produced and consumed" (Durst \& Bayasgalandbat, 2014). A number of authors have suggested studying underutilized crops and their (re)adoption, since they 
have the potential to mitigate environmental risks in agricultural production systems, improve nutrition, generate income, maintain the health of ecosystems and contribute to the development of biological and cultural diversity (Padulosi, et al., 2014) (Williams \& Haq, 2002).

The term underutilized "is commonly applied to refer to species whose potential has not been fully realized” (Durst \& Bayasgalanbat, 2014). Paludosi et al. define underutilized crops as crops that receive little attention from agricultural researchers, plant breeders and policy makers. Paludosi et al. (2014) use a fluid definition of the term underutilized crops "as when a crop is simultaneously a well-established major crop in one country and a minor crop in another" (Paludosi et al., 2002) (Padulosi et al., 2014).

The protein deficit and climate change challenge in the EU

Currently the European Union imports about $80 \%$ of its protein needs (Hausling, 2011), (Ramwar \& Siew, 2017). The main protein crops have been soybeans and maize. For this reason, the European Commission and the member states have suggested a more diversified strategy. The new strategy aims to respond more directly to climate change, loss of biodiversity, soil depletion, water consumption and price volatility of agricultural protein products on the world market (Hausling, 2011) (Maggio, et al., 2016).

Warmer temperatures due to climate change are already affecting agricultural productivity in different ways. In particular, Mediterranean and other southern areas of Europe will face extreme heat events and a reduction in precipitation and availability of water, which will lead to lower crop yields (European Environment Agency, 2015). The negative consequences of climate change for agricultural production have brought attention to building resilience into agriculture systems by increasing crop diversification (Matson et al., 1997), (Lin, 2011). Diversification has also been recommended as a "smart solution" by the EU (European Commission, 2015) to reach the objectives the EU has set itself.

There are different crop systems with high protein content: legumes such as lima beans and other beans, etc., old varieties of cereals that have been neglected for commercialization, wild edible plants, or pseudo-cereals such as quinoa and amaranth (Gillman, 2017). The latter two crops have been widely studied for their nutritional attributes and high protein content (Escobedo-López et al., 2014; Escobedo-Lópe, et al., 2014) or for their contribution to biodiversity and the environment (Rastogui \& Shukla, 2011).

Underutilized crops with high protein content can not only increase biodiversity, but also substantially reduce greenhouse gas emissions through the assimilation and fixation of nitrogen to the soil, thus reducing ozone production in the EU by $10-15 \%$ (Hausling, 2011). Therefore, considering the EU's climate situation, the lack of biodiversity, and the large protein deficit, it is highly relevant to (re)adopt underutilized crops in the EU to develop new and sustainable value chains.

The (re)adoption challenge

Most of the underutilized crops have either been important crops in the past in Europe or originate from other regions of the world (Stamp, et al., 2012. Today however, there is a lack of knowledge about how to (re)adopt such crops (Williams \& Haq, 2002).

As is stated in the report on the EU protein deficit: 
"The most worrying fact is that throughout Europe, practical experience in protein crop production as part of extended crop rotation is being lost, including on-farm selection, storage, processing and on-farm use as animal feed." (Hausling, 2011)

The report suggests studying how to improve knowledge and create market conditions such as shortening supply chains as well as adopting certified production models in order to favour local production of the neglected crops (Hausling, 2011).

Quinoa and amaranth are examples of underutilized crops with high protein content and are also important sources of the amino acid lysine. Both quinoa and amaranth have been studied as important alternatives to soybeans, as their nutritional and functional properties are equal to or better than soybeans (Gorinstein et al., 2001) (Drzewiecki et al., 2003). However, even though amaranth is an ancient native crop in Mexico, its cultivation has not been widely diffused (Howard, 2013). Studies have concentrated on technical assistance, which has helped in readopting this crop, but production is still mainly for subsistence consumption (Howard, 2013). It has been suggested to study consumer acceptance, in relation to which efforts have been directed towards writing cookery books. However, people do not include the new food products in their everyday diets (Howard, 2013).

Consequently, and considering all the above-mentioned challenges, we need research that is both transdisciplinary and sustainability-based.

Sustainability in this article follows the recommendations of the United Nations Environment Programme concerning food security and organic production. The UNEP considers that a production system can only be labelled sustainable if it makes the best use of environmental goods and services, while reducing and avoiding adverse system effects with regard to natural, social, and human capital (UNEP - UNCTAD, 2008). In other words, a production system needs to consider all three pillars of sustainability, the environmental, economic and social pillars, in order to be called sustainable.

The main questions are therefore: What constraints need to be considered in order to foster sustainability in new value chains for (re)adopting underutilized crops, and is there already a holistic framework to do so?

In the first part of this article, we analyse the state-of-the-art of the research perspectives that have been suggested to investigate the adoption of underutilized crops. We analyse the most typical constraints. We also explore whether these constraints have been studied in a holistic framework. In the second part of the article, we discuss these issues against the theoretical background of the three pillars of sustainability, (environmental, economic and social), and the identified constraints. Finally, we suggest a new holistic framework.

\section{Methods}

First, we made a list of key words. The list was constructed partly on the basis of theoretical considerations and our own previous research experience in the field and partly on preliminary reading of relevant studies (ACP, 2012) (Forster, et al., 2012), (Jacobsen. et al., 2015) and (Baldermann et al., 2016). The words in the list were then confirmed through examination of the results of the search. The main search term was "underutilized crops". Second, we added issues that are often mentioned or considered 
as constraints for the adoption of underutilized crops. Grouping them by themes, we finally selected the following key words: technology, value chain, market, health effects, environmental effects, adoption, social networks, cultural acceptability and infrastructure. In order to reaffirm the list and to see which of the constraints had received more attention in the promotion of new value chains for (re)adopting innovative food crops, we conducted three surveys using Google Scholar. The first survey considered articles published from 2006 to 2016 using the term "underutilized crops", and revealed 2240 articles.

In the second survey, we added each of the following key words individually: AND "value chain" AND "adoption" AND "cultural acceptability" AND "social networks" AND "technology" AND "market" AND "environmental effects" AND "health effects". The survey did not include patents or citations (see Table 1).

The third survey focused on articles that discussed more than one issue at the same time in the same article in the same period. Consequently, the survey again used scholar.google.dk. The selection of articles was made using all the following key words at the same time: underutilized crops, value chain, adoption, cultural acceptability, social networks, technology, market, environment, resource effects, health effects. The articles were selected by relevance to the key words and the search did not include patents or citations. The total result was 74 sources. A further selection filter was applied by reading the materials and selecting only scientific articles, reports, books, book chapters or documents from official institutions. From this selection, 48 sources remained (see Table 2). This review was performed to determine whether the key words actually formed part of the study in the text or if they only pointed to further research.

In order to ascertain whether there were articles with a holistic approach (considering all the constraints suggested at the same time), a fourth survey was conducted using the following key words "underutilized crops", AND "value chain" AND "adoption" AND "cultural acceptability" AND "social networks" AND "technology" AND "market" AND "environmental effects" AND "health effects" AND "infrastructure". However, there were zero results for this last survey.

To suggest a new holistic approach, we grouped the identified main constraints in relation to the different pillars of sustainability, and finally we discussed the main theoretical background of the constraints as contextual conditions for the development and adoption of sustainable new value chains.

\section{Literature review}

By only searching for the key word “underutilized crops” from 2006 to 2016, 2240 articles were found.

Table 1 shows the results of the second survey. It reveals that the most often overlapping key word between 2006 and 2016 was "technology", followed by "market", "adoption" and "infrastructure".

Studies where the key word was "technology" overlapped more often with the key word "market" than with the key word "value chain". However, considering only the market might not provide the entire picture of the limiting factors for implementation of the underutilized crops. Focusing more on the whole value chain instead of only on the 
market can help to prevent failures of flow in considering the effectiveness of the whole value chain to reach the market (Gereffi \& Kaplinsky, 2001).

The key word "adoption" seems to be more connected to "technology", "market", and "infrastructure" than to "environmental" and "health effects". It is also strange that studies where the central key word is "adoption" do not overlap more often with the key word "cultural acceptability" as cultural acceptability is one of the main elements of the diffusion of innovation theory. Notably, the key word "adoption" is often related to "market" rather than to the "value chain".

When considering that the definition of underutilized crops has to do with a broader utilization of new crops, it is worth noting that the number of articles using the key word "adoption" suggests little attention to this in research.

Considering the number of studies on technology (1560) overlapping with the number of social network studies (14), a remarkably weak relationship is seen between the production of knowledge and how this is actually distributed and who is driving the direction of its development. It is also remarkable that the overlapping categories of technology and cultural acceptability (5 documents) also indicate a need for further studies considering both of these constraints at the same time.

When searching for the key words "underutilized crops" AND "adoption", 531 articles were found. Given the number of articles, the adoption issue appears relevant to the study of underutilized crops.

Table 1. Most overlapping constraints regarding the value chains of underutilized crops in articles from 2006 to April 2016

\begin{tabular}{|c|c|c|c|c|c|c|c|c|c|}
\hline "Underutilized crops" & 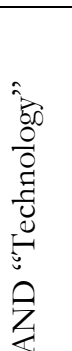 & 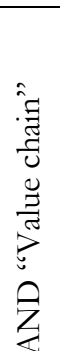 & 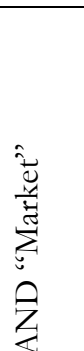 & 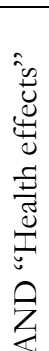 & 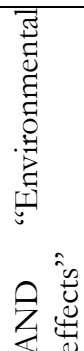 & 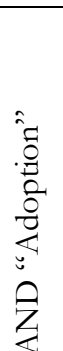 & 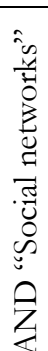 & 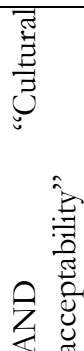 & 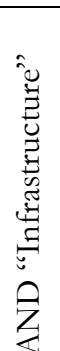 \\
\hline AND “Technology" & 1560 & 207 & 941 & 77 & 52 & 422 & 14 & 5 & 351 \\
\hline AND "Value chain" & & 250 & 243 & 10 & 11 & 137 & 5 & 2 & 134 \\
\hline AND "Market" & & & 1280 & 65 & 46 & 420 & 15 & 7 & 353 \\
\hline AND "Health effects" & & & & 93 & 2 & 17 & 1 & 1 & 28 \\
\hline $\begin{array}{l}\text { AND "Environmental } \\
\text { effects" }\end{array}$ & & & & & 65 & 28 & 0 & 0 & 28 \\
\hline AND “Adoption” & & & & & & 531 & 43 & 4 & 211 \\
\hline AND "Social networks" & & & & & & & 63 & 0 & 35 \\
\hline $\begin{array}{ll}\text { AND } & \text { "Cultural } \\
\text { acceptability" } & \end{array}$ & & & & & & & & 7 & 4 \\
\hline AND "Infrastructure" & & & & & & & & & 404 \\
\hline
\end{tabular}

When focusing on holistic studies (containing several constraints at the same time: the third review), we filtered the 74 documents and ended with 48. From these we 
constructed Table 2. Table 2 is a check list that indicates which of the constraints were in fact analysed in the article or document; this is marked with the symbol $\sqrt{ }$. Topics suggested by the authors for further research are marked with $(+)$. In places where $(-)$ and $(+)$ are shown at the same time, this indicates that the issue was mentioned but not analysed in the document itself; however, the author(s) recommend further research in that direction (see Table 2).

The 48 reviewed documents show that the studies deal with the implementation of the cultivation of such crops in developing countries, but none of the reviewed articles presented a case where the cultivation of underutilized crops is promoted in developed countries, including the European Union.

The role of developed countries, especially when the crop is promoted as functional food or as gluten free food, is only at the end of the value chain, in other words only in marketing and directed at consumers but not as producers. The food security policies and the huge EU dependency on imported protein calls for the adoption of innovative crops with high protein content also within the EU. The adoption of underutilized crops will not only mitigate the huge dependency on protein, but it can also enhance biodiversity. According to Ceccarelli et al. ( 2013) it will also reduce the negative impact of climate change on agriculture and consequently on food production caused by the greater uniformity that exists now compared to 150-200 years ago, particularly in the agricultural crops of developed countries.

Table 2 presents the constraints or drivers that we made prior to the search and includes additional constraints that will be discussed in the next section, such as gender, policy, and capacity building.

As we mentioned, there were 2240 hits when we searched for "underutilized crops" alone. When looking for documents that had analysed more than two constraints, we ended with 48 documents. The closer look at the 48 documents revealed 19 documents that point to the fact that there is a lack of further research considering other constraints at the same time (where + symbol is indicated). Out of these 19 documents, 6 documents recognized in their final conclusion that including, at the same time, the research on policies that support the development of science, technology and market for the creation of new value chains would have provided a better understanding of the implementation issues. Nevertheless, there was only one document out of the 48 that specifically recognized the need for a more holistic perspective (ACP, 2012).

We concur with Forster et al. who state in their analysis of the drivers of innovation in innovative crops research that: "There is a lack of more systemic and holistic approaches and research" (Forster, et al., 2012). The need for holistic approaches becomes more apparent if a sustainable adoption of innovative systems for the cultivation of underutilized crops is really wanted by European and international institutions; firstly, because to provide a systemic solution one has to include the whole value chain system and secondly, because one has to try to consider all the most relevant contextual issues that affect the adoption of such crops.

Even though the volume of research identified through our search has evidenced the important issues that influence the (re)adoption process for underutilized crops, we can also conclude, based on the same volume of research, that there is no comprehensive 
framework that summarizes the findings into a holistic understanding of the issue of fostering sustainable innovative value chains for the (re)adoption of underutilized crops.

Table 2. Articles including more than one constraint for the analysis of the re-adoption of topdown recommended underutilized crops

\begin{tabular}{|c|c|c|c|c|c|c|c|c|c|c|}
\hline 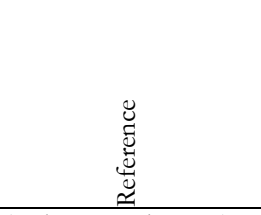 & 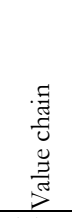 & 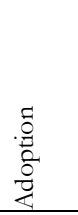 & 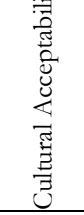 & 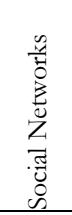 & $\begin{array}{l}\text { con } \\
0 \\
0 \\
0 \\
0 \\
0 \\
-0 \\
\end{array}$ & 节 & 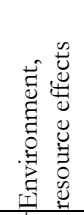 & 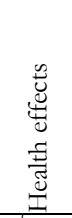 & 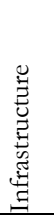 & 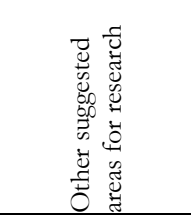 \\
\hline (Kahane, et al., 2013) & $(+)$ & & $\begin{array}{l}(-) \\
(+)\end{array}$ & & $\begin{array}{l}(-) \\
(+)\end{array}$ & & $\sqrt{(+)}$ & $\sqrt{ }$ & & \\
\hline (Ebert, 2014) & $(-)$ & $\sqrt{ }$ & $(-)(+)$ & $\sqrt{ }$ & - & & & & & \\
\hline $\begin{array}{l}\text { Jacobsen S.-E. } \\
\text { Sørensen, Pedersen, \& } \\
\text { Weiner, 2013) }\end{array}$ & & & & & $\sqrt{(+)}$ & $(+)$ & $\sqrt{(+)}$ & $\begin{array}{l}(-) \\
(+)\end{array}$ & & $\begin{array}{l}\text { Policy research } \\
\text { \& governance }\end{array}$ \\
\hline $\begin{array}{lr}\text { Allen, } & \text { Prosperi, } \\
\text { Cogill, \& } & \text { Flichman, } \\
\text { 2014) }\end{array}$ & $\begin{array}{l}(-) \\
(+)\end{array}$ & & $\begin{array}{l}(-) \\
(+)\end{array}$ & & & & $\sqrt{ }$ & $\sqrt{ }$ & & \\
\hline (Leakey, et al., 2006) & $\sqrt{ }$ & $\begin{array}{l}(-) \\
(+)\end{array}$ & & & & $\sqrt{ }$ & $\sqrt{ }$ & $\sqrt{ }$ & & \\
\hline (Watson, 2008) & $\begin{array}{l}(-) \\
(+) \\
\end{array}$ & $(-)(+)$ & $\begin{array}{l}(-) \\
(+) \\
\end{array}$ & & $\begin{array}{l}(-) \\
(+) \\
\end{array}$ & $\begin{array}{l}(-) \\
(+) \\
\end{array}$ & $\begin{array}{l}(-) \\
(+) \\
\end{array}$ & & & \\
\hline (Hilger, et al., 2015) & & & & $(-)(+)$ & $\sqrt{1}$ & & $\sqrt{(+)}$ & & & \\
\hline (Feuer \& Garb, 2006) & & & & $\sqrt{ }$ & & & & & & $\begin{array}{l}\text { National } \\
\text { policies or plans }\end{array}$ \\
\hline $\begin{array}{lll}\text { (Brussaard, et al., } \\
2010)\end{array}$ & & & & $\sqrt{(+)}$ & & & $(+)$ & & & \\
\hline $\begin{array}{l}\text { (Baldermann, et al., } \\
\text { 2016) }\end{array}$ & $\sqrt{(+)}$ & $\begin{array}{l}(-) \\
(+)\end{array}$ & $\sqrt{(+)}$ & $\sqrt{(+)}$ & $\sqrt{(+)}$ & $(-)(+)$ & $\begin{array}{l}(-) \\
(+)\end{array}$ & $\sqrt{(+)}$ & & $\begin{array}{l}\text { Policy- } \\
\text { supported } \\
\text { extension } \\
\text { services to local } \\
\text { farmers }\end{array}$ \\
\hline (Forster, et al., 2012) & & & & $\begin{array}{l}(-) \\
(+)\end{array}$ & $\sqrt{(+)}$ & & $\sqrt{(+)}$ & & & $\begin{array}{l}\text { Political } \\
\text { dialogue and } \\
\text { intervention in } \\
\text { agricultural } \\
\text { research }\end{array}$ \\
\hline (Rudebjer, et al., 2011) & & & & & & & & & & $\begin{array}{l}\text { Capacity } \\
\text { building }\end{array}$ \\
\hline $\begin{array}{l}\text { (Onyema, Osuagwu, \& } \\
\text { Ekpenyong, 2013) }\end{array}$ & & $\begin{array}{l}(-) \\
(+)\end{array}$ & $\sqrt{ }(+)$ & $\sqrt{(+)}$ & $\sqrt{(+)}$ & & & & & \\
\hline $\begin{array}{l}\text { Jacobsen S.-E. } \\
\text { Sørensen, Pedersen, \& } \\
\text { Weiner, 2013) }\end{array}$ & & & & & & & $\sqrt{ }$ & $\sqrt{ }$ & & \\
\hline $\begin{array}{l}\text { (Bellon, Gotor, \& } \\
\text { Caracciolo, 2015) }\end{array}$ & $\sqrt{ }$ & & & & & & $\sqrt{ }$ & & & \\
\hline $\begin{array}{l}\text { (Bhullar \& Bullar, } \\
\text { 2013) }\end{array}$ & & $\sqrt{ }$ & & $(-)(+)$ & $\sqrt{ }$ & & $\sqrt{ }$ & & & \\
\hline (Padulosi, et al., 2014) & $\sqrt{ }$ & & $\sqrt{ }$ & $\sqrt{ }$ & $\sqrt{ }$ & $\sqrt{ }$ & $\sqrt{ }$ & & & \\
\hline (Hewet, 2012) & & & & & $\sqrt{ }$ & & $\sqrt{ }$ & & & \\
\hline $\begin{array}{l}\text { Nuijten, Messmer, \& } \\
\text { Lammerts van Bueren, }\end{array}$ & & & & & $\sqrt{ }$ & & & & & \\
\hline
\end{tabular}




\begin{tabular}{|c|c|c|c|c|c|c|c|c|c|c|}
\hline 2017) & & & & & & & & & & \\
\hline (Herforth, 2010) & & & $\sqrt{ }$ & $\sqrt{ }$ & & $\sqrt{ }$ & & & $\sqrt{ }$ & \\
\hline $\begin{array}{l}\text { (Irungu, Mburu, \& } \\
\text { Maundu, 2007) }\end{array}$ & $\sqrt{ }$ & & $\sqrt{ }$ & $\sqrt{ }$ & $\sqrt{ }$ & $\sqrt{ }$ & $\sqrt{ }$ & $\sqrt{ }$ & & Policies \\
\hline $\begin{array}{l}\text { (Fasoyiro \& Taiwo, } \\
\text { 2012) }\end{array}$ & $\sqrt{ }$ & & $\sqrt{ }$ & $\sqrt{ }$ & $\sqrt{ }$ & $\sqrt{ }$ & $(+)$ & $\sqrt{ }$ & & Gender \\
\hline (Wolfenson, 2013) & $\sqrt{ }$ & & & $\sqrt{ }$ & & & $\sqrt{ }$ & & & \\
\hline $\begin{array}{l}\text { (Hawkes, Turner, \& } \\
\text { Waage, 2012) }\end{array}$ & $\sqrt{ }$ & & & & & & & & $\sqrt{ }$ & \\
\hline (Raviv, 2010) & & & & & & & $\sqrt{ }$ & & & \\
\hline $\begin{array}{l}\text { (Vernooy, Jingsong, \& } \\
\mathrm{Li}, 2008 \text { ) }\end{array}$ & $\sqrt{ }$ & & & & & & $\sqrt{ }$ & & & Policies \\
\hline $\begin{array}{l}\text { (Ramwar \& Siew, } \\
\text { 2017) }\end{array}$ & & & & $\sqrt{ }$ & $\sqrt{ }$ & & $\sqrt{ }$ & & & \\
\hline (Leanne, 2014) & $\sqrt{ }$ & & & & & $\sqrt{ }$ & $\sqrt{ }$ & & $\sqrt{ }$ & \\
\hline $\begin{array}{l}\begin{array}{l}\text { Sajise } \\
2008)\end{array} \\
\text { \& Ahmad, }\end{array}$ & $\sqrt{(+)}$ & $(+)$ & & $\sqrt{ }$ & & & $\sqrt{ }$ & & & \\
\hline $\begin{array}{l}\text { (Sthapit \& Gauchan, } \\
\text { 2006) }\end{array}$ & $\sqrt{ }$ & & & & $\sqrt{ }$ & $\sqrt{ }$ & $\sqrt{ }$ & & & \\
\hline (ACP, 2012) & $\sqrt{ }$ & & & & & $(+)$ & & & & \\
\hline (Hanson, 2016) & $\sqrt{ }$ & & & & & & $\sqrt{ }$ & $\sqrt{ }$ & & \\
\hline (Keatinge, et al., 2015) & $\sqrt{ }$ & & $(+)(-$ & & $\sqrt{ }$ & & $\sqrt{ }$ & & & \\
\hline $\begin{array}{l}\text { (Sharma \& Wightman, } \\
\text { 2015) }\end{array}$ & $\sqrt{ }$ & & & & & & $\sqrt{ }$ & & & \\
\hline $\begin{array}{l}\text { (Mal, Paludosi, \& Bala } \\
\text { Ravi, 2010) }\end{array}$ & $\sqrt{ }$ & $(+)$ & & & $\sqrt{(+)}$ & & & & & \\
\hline (Ndegwa, 2016) & $\sqrt{ }$ & $(+)$ & & $(+)$ & & $\sqrt{(+)}$ & & & & \\
\hline (Jones, 2014) & $\sqrt{ }$ & $\sqrt{(+)}$ & & & & & & & & \\
\hline (Turok, 2001) & & & & & & & $\sqrt{ }$ & & $\sqrt{ }$ & \\
\hline (Gonzalves, 2013) & & & & $\sqrt{ }$ & & & & & & \\
\hline (Onyango, 2010) & & $\sqrt{(+)}$ & & & $\sqrt{ }$ & & $\sqrt{ }$ & & $\sqrt{ }$ & \\
\hline (Peter, 2008) & & & & & & & $\sqrt{ }$ & & & \\
\hline $\begin{array}{lr}\text { Fanzo, } & \text { Hunter, } \\
\text { Borelli, \& } & \text { Mattei, } \\
2013)\end{array}$ & & & & $\sqrt{ }$ & & & $\sqrt{ }$ & $\sqrt{ }$ & & \\
\hline $\begin{array}{l}\text { (Hrideek } \\
\text { Nsmpoothiri, 2016) }\end{array}$ & & & & & & & $\sqrt{ }$ & $\sqrt{ }$ & & \\
\hline $\begin{array}{l}\text { (Christinck \& } \\
\text { Padmanabhan, 2013) }\end{array}$ & $\sqrt{ }$ & & & & & $\sqrt{ }$ & $\sqrt{ }$ & & & \\
\hline $\begin{array}{l}\text { (Cork, Dobson, } \\
\text { Grzywacz, \& Hodges, } \\
2009 \text { ) }\end{array}$ & & & & & $\sqrt{ }$ & & $\sqrt{ }$ & & & \\
\hline (Chittarajan , 2013) & & & & & $\sqrt{ }$ & & $\sqrt{ }$ & & & \\
\hline (Ferguson, 2015) & & & $\sqrt{ }$ & & $\sqrt{ }$ & & $\sqrt{ }$ & & & \\
\hline (Mwamba, 2006) & $\sqrt{ }$ & & & & $\sqrt{ }$ & & $\sqrt{ }$ & & & \\
\hline
\end{tabular}




\section{Theoretical background of the main constraints or drivers and their effect on the realization of sustainable adoption strategies}

As we mentioned above, a sustainable crop system needs to consider the three pillars of sustainability in order to be labelled sustainable. But a holistic approach needs to consider the three dimensions at the same time to avoid distorted solutions; as depicted in Figure 1, the three dimensions of sustainability are interconnected and affect each other.

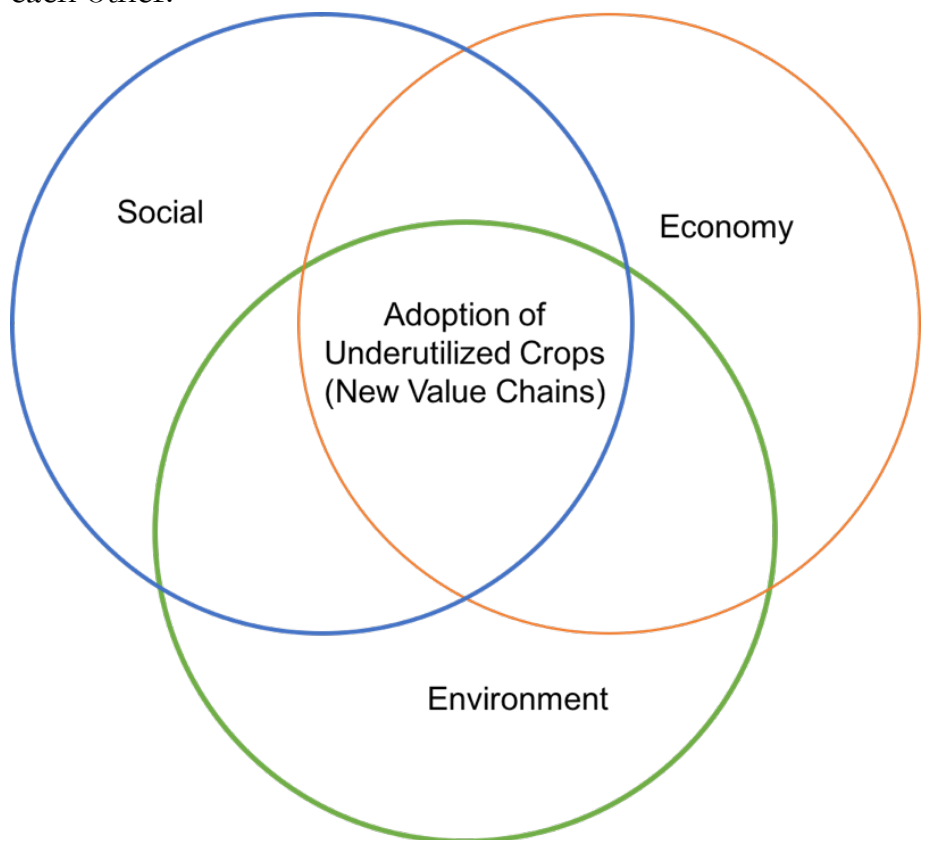

Fig 1. The three pillars of sustainability that are needed to support sustainable adoption of underutilized crops.

In the following, we will discuss all the dimensions of a comprehensive framework for fostering sustainable and innovative value chains for the (re)adoption of underutilized crops. We will include relevant aspects of all the three pillars of sustainable development together with the drivers identified through the state-of-the-art analysis. Since the discussion is theoretically oriented rather than thematic as in the state-of-the-art analysis, we have organized it in a somewhat different structure than the one used in the tables above in order to make clearer the theoretical presentation of the issues.

\section{Adoption of an innovation}

Although underutilized crops have been recommended by institutional policies, these crops might be unfamiliar to farmers, especially considering that these crops are not geographically endogenous. Therefore, it is important to draw attention to the concept of innovation. The concept of innovation or the quality of being innovative is in this paper outlined by the following definition:

"An innovation is an idea, practice or object that is perceived as new by an individual or other unit of adoption. It matters little, so far as human behaviour is concerned, whether or not an idea is 'objectively' 
new as a measure by the lapse of time since its first use or discovery. The perceived newness of the idea for the individual determines his or her reaction to it. If the idea seems new to the individual, it is an innovation" ... Newness' of an innovation may be expressed in terms of knowledge, perception, or a decision process." (Rogers, 2003)

This may be the case for ancient crops that for either geographical or historical reasons are unknown to individuals or farmers.

Adoption of innovative food has played a major role historically. The case of the potato is perhaps one of the most famous examples. It was once an exotic local food from South America and is now a widespread crop and food. Another example is amaranth: it was once considered sacred in Aztec culture, later to be banned by colonialists, and has now been rediscovered as a new food with great economic, social, and environmental benefits.

\section{The adoption process: values, perceptions and culture}

Cultural acceptability may act as a constraint for the adoption process, according to the diffusion of innovation (DI) theory (Rogers, 2003). This theory highlights the issues of values, perceptions and time to measure the rate of adoption or to strategically speed up the process of adoption.

According to Rogers, it is useful to use knowledge and information produced in social networks to reduce uncertainty and perceptions of risk. However, he emphasizes that it is possible to spread an innovation faster if strategic channels of communication are used. To achieve this goal, he suggests targeting "opinion leaders" and "first movers" in the social network. Moreover, DI theory contributes by analysing the values, perceptions and culture of the adopters, emphasizing that potential adopters' perceptions of the characteristics of an innovation influence their adoption decisions (Rogers, 2003)

In order to speed up the rate of adoption (in this case the adoption of underutilized crops), Rogers suggests also considering the set of interrelated units that are engaged in joint problem solving to accomplish a common goal. The members or units of a social system, as he calls it, may be individuals (also gender related), informal groups, organizations and/or subsystems (Rogers, 2003). The goal might be an economic benefit, a new livelihood, or just an innovation. Nevertheless, the knowledge, the resource endowments and social relationships that might be derived from the same activity or field seem to be a common motivation to cultivate these relationships (Rogers, 2003).

Furthermore, it has been indicated that the existence of social relationships enables the achievement of certain ends that might not otherwise be attainable (Svendsen, 2001). A more developed theory to study such relationships has been the social network theory, based on the concept of the development of social capital (Svendsen, 2001), (Vargas Vallejos, et al., 2008).

Since adopting new crops might result in an added value, it also becomes part of an economic system. Rogers recognizes the fact that future research on the diffusion of innovation should take into consideration economic equality and how the benefits of adopting or re-adopting something new are distributed between the individuals adopting such innovation. He underlines that this kind of analysis is often lacking in innovation research (Rogers, 2003). We argue that one possible approach to analysing economic equality and distribution of benefits is to include elements from value chain theory. 


\section{Social networks and social capital}

The production of knowledge, how this knowledge is actually distributed and who is driving the direction of its development could be explained using social network theory. At the core of social network theory is the concept of social capital, which points out the importance of social relations and mutually binding relationships or reciprocity (Vargas Vallejos, et al., 2008) (Svendsen, 2001). The concept of social capital has evolved and has had important contributors such as Weber, Marx, Bourdieu, Coleman, and Putnam. But in this paper, we follow Putnam's definition in which social capital is embodied in norms and networks of civic engagement as a precondition for economic development and for effective governance (Putnam, 1993).

Social network theory has moreover been the stepping stone to the collaborative network studies that seek to analyse and quantify such relationships in the distribution of knowledge, as well as identifying who the main actors are and in which direction the actors are driving the development of the production system (Vargas Vallejos, et al., 2008). We consider that value chains are partly rooted in national contexts and partly in globalized contexts, and therefore it is useful to consider both dimensions to achieve successful diffusion. Neglecting one or the other will result in partial solutions or strategies that do not respond to regional differences. Zhou et al. (2007) argue that social networks are useful to reduce barriers to information and knowledge, and that they can support key capabilities in terms of speed and flexibility to respond to both national and global markets (Zhou, et al., 2007).

Coleman (1998) emphasizes that all associated resources are results of the interactions in the social network (Coleman, 1988). On the other hand, Svendsen (2001) stresses the importance of assets endowments such as land, credit, farm inputs or economic incentives, which are necessary to support a production system (Svendsen, 2001). Considering that such endowments are necessary to support the development of new value chains, it is important to take them into account. Thus, considering who the main actors are and what knowledge they have is not enough to produce a change. To induce a change, one has to further analyse, at the same time, the resources and assets that constrain the adoption of a new crop.

Furthermore, social network and social capital theories are relevant to find and identify the actors and the knowledge but they fail to explain how to induce a change in the decision process and how to work with the strategic actors to produce that change more efficiently.

Considering that "...people's behaviour is determined in part by their embeddedness in social networks" (Monge, et al., 2008), we propose to combine social network theory with diffusion of innovation theory, precisely to enable a better analysis of the behavioural issues that might constrain the adoption process. By doing so, we could likewise argue for a more strategic and faster diffusion process.

\section{Market constraints and the value chain}

Whereas diffusion of innovation and social network theories (and more specifically the concept of social capital) focus on the social dimension of sustainability, the value chain approach can contribute the economic pillar. The value chain concept refers mainly to the series of added value activities, according to Porter (1985). The series encompasses primary activities (manufacture, sales and distribution) and the secondary activities 
(planning, finance, $\mathrm{R} \& \mathrm{D}$ and human activities) that normally support the primary activities in an organization or company. While Porter's focus was set more on a regional basis, Gereffi \& Kaplinsky (2001) enlarged the focus to a macro level, in considering globalization in relation to the development of new value chains in international financial activities with global organization.

We look at global organization with specific emphasis on the knowledge transfer that is provided via the value chain relationships (Saliola \& Zanfei, 2009), (Giulani, et al., 2005). As mentioned above, underutilized crops might not be indigenous to the places where they are to be cultivated, or they might be ancient crops and therefore the knowledge and technology required to cultivate them might be forgotten or outdated. Considering the global value chain can help to fill that knowledge gap instead of starting from scratch.

\section{Environmental and resource issues}

The process of starting or joining a new value chain requires a transition from one activity to another, and perhaps the use of new technology and new knowledge. It might also require the construction of or access to a new social network, or the use and management of different natural/physical resources. Production and consumption of farm products nowadays raise many political concerns such as food security, health, biodiversity, resource consumption and $\mathrm{CO}_{2}$ emissions levels. All these issues require an interdisciplinary and holistic approach. Leaving one of these issues unattended will give distorted solutions. The convergence of natural, economic, and social issues has to be considered for a successful adoption and diffusion strategy.

The concept of sustainability has evolved since it was first described as "development that meets the needs of the present without compromising the ability of the future to meet their own needs" by the World Commission on Environment and Development (Brundtland, 1987). The original concept considered two interrelated spheres of concern, environment and development. Emphasizing that the development issue is both social and economic, the concept of sustainable development evolved into a three-pillar model (Gibson, 2001). There have been important discussions about why to integrate the environmental issue into the analysis and management of value chains. Important arguments in this debate have concerned the inherent natural constraints (access to raw materials, etc.) (Fearne, 2009), political reasons (new legislation and regulations) (Gibson, 2001) or pursuance of a competitive advantage (Porter, 1985).

Attention to environmental constraints in value chains has increased due to the utilization of raw materials and their impact on the environment from the initial processing of products, their commercialization and their subsequent disposal. Industrial ecology has contributed to this discussion by analysing the environmental dimensions of the product design, manufacturing by-products, product management during the product use, product life extension and product end of life (Linton, et al., 2007). Accordingly, Linton et al. (2007) point out tools such as the life cycle assessment approach, which considers the impact on resource availability and the environmental impact from the product design to the end of life of a product. They also mention the importance of not only considering the optimization of the product from its current standpoint but also from a total cost standpoint. 
The importance of environmental considerations is also seen in relation to competitive advantage, since reducing materials and waste can also reduce costs in production and distribution and create added value important for society (Porter, 1985).

\section{Life cycle perspective}

As the focus is on the development of new production systems and their impact on the current environmental and resource situation, and since we are arguing for a whole value chain approach, it is important to consider the entire life cycle of the production process. Life cycle analysis, by definition, requires an assessment to be made of the environmental impact of a product from input supply to final consumption and end of life. According to Fearne (2009), combining the value chain perspective and a life cycle analysis provides the tools for both economic and environmental improvements of the products or production systems by reducing resource consumption and environmental impacts (Fearne, 2009)

Implementing food value chains that are considered by international institutions to be more resilient, more diverse, or that help to reduce the strong dependency on protein imports of a country might not be convincing arguments for small-scale farmers to take up a different course of action. These arguments might be even less convincing for farmers having success with what they actually do. Even unsuccessful farmers will be reluctant to engage or re-engage in value chains that are unfamiliar, unless they see some other benefits for their business and get access to the proper technology, knowledge and production network. The main intention of international institutions in suggesting the adoption of new crops is the benefit to society, but that might not represent a direct income or a strong incentive for the actors involved. At least the rate of adoption would not be as fast as desired, if all the constraints that are relevant to causing extensive social changes around the production system are not considered and overcome. This issue has been explored in the area of technological eco-innovation (Andersen, et al., 2006).

\section{Technological and market policies}

The studies analysed here indicated the necessity for further research on policies that support the development of science, technology and market for the creation of new value chains (Jacobsen, et al., 2013; Feuer \& Garb, 2006; Vernooy, et al., 2008; Irungu, et al., 2007; Forster, et al., 2012; Feuer \& Garb, 2006; Baldermann, et al., 2016).

We argue that it is important to study both science, technology and market at the same time. According to Nemet (2009), there are two types of drivers that motivate changes towards innovation, namely technological and market drivers. The first might be motivated by pure scientific or experimental curiosity that then results in new methods or technologies. The second one is linked to changes in market conditions such as rising commodity prices, geographical changes in demand, and identification of new markets and trends. Nemet (2009) argued that considering one factor independently of the other would result in wrong planning, as such drivers are inadequate in themselves. He says: "science-and technology-push fails to account for market conditions, while demand-pull ignores technological capabilities" (Nemet, 2009).

It is noteworthy that the studies analysed here remark in their conclusions that policies are needed either to support the technology or to create a market, but that this issue has been neglected in spite of its vital influence. It is also important to note that there are a large number of studies taking into consideration either technology or market drivers; 
often such studies consider them independently of each other (ACP, 2012; Vernooy, et al., 2008; Baldermann, et al., 2016 and Forster, et al., 2012).

\section{Push-pull drivers or policies}

In relation to the technological and market drivers, several authors (Kline \& Rosenberg, 1986; Rennings, 2000; Cleff \& Rennings, 2000) have pointed out a third kind of drivers: push-pull drivers, also called policy or regulation push-pull mechanisms. The point is that both the push and pull policies have to be considered at the same time and not in isolation. This interdependency plays an important role to speed up the rate of innovation or adoption of top-down ${ }^{1}$ recommended technologies or production processes (Bjarklev, 2012). These policy instruments can be either regulations, economic means that support the generation of new scientific knowledge, or new technologies or policy instruments that facilitate new markets by generating new needs or using demandside policies. It is important to create financial and policy opportunities for the research and development of knowledge and technologies for the adoption of new crops. Equally important is the development of policy instruments that ensure a market for these products at the same time. International guidelines or European suggestions might not be enough, if individual governments do not provide the necessary support or political pull in the direction of these changes, particularly the inclusion of underutilized crops in national plans or strategies. In other words, the more systemic (considering the whole value chain system) and holistic the efforts for the adoption (considering the most important contextual constraints), the more successful and faster the rate of adoption will be.

\section{The need for a holistic framework}

Using the suggestions in studies analysing the adoption of underutilized crops and drawing on the above theoretical discussion, we suggest a new model (based on Figure 1) to study the development of sustainability in innovative value chains when (re)adopting underutilized crops.

The model suggested here (Figure 2) is a result of reflection on and synthesis of different analyses involved in research on the adoption and re-adoption of underutilized crops (see Table 2). This model draws on relevant considerations from the theories of diffusion of innovation, social networks, global value chain, life cycle perspective and drivers of innovation, framed by the three pillars of sustainability.

Based on our compilation of suggested constraints in the field of (re)adoption of underutilized crops and the theoretical considerations, we would argue that the model proposed here can help to structure more holistic research in this area. Such research, grounded in climate, biodiversity and the environment, should consider these factors to improve planning and speed up the rate of adoption of such crops. Moreover, the model can be used to provide more nuanced explanations of the conditions necessary to overcome constraints and accelerate adoption, in order to implement similar innovations, which would facilitate the extrapolation of results.

\footnotetext{
${ }^{1}$ We call these "top-down strategies" since they are suggested by international institutions.
} 
The model has a systemic perspective as it considers the whole value chain system. It is a holistic model in depicting the constraints that occur at the environmental, social and economic levels of the adoption of top-down recommended food crops. The model depicts the overlap of pillars as they affect each other in relation to the final result or strategy.

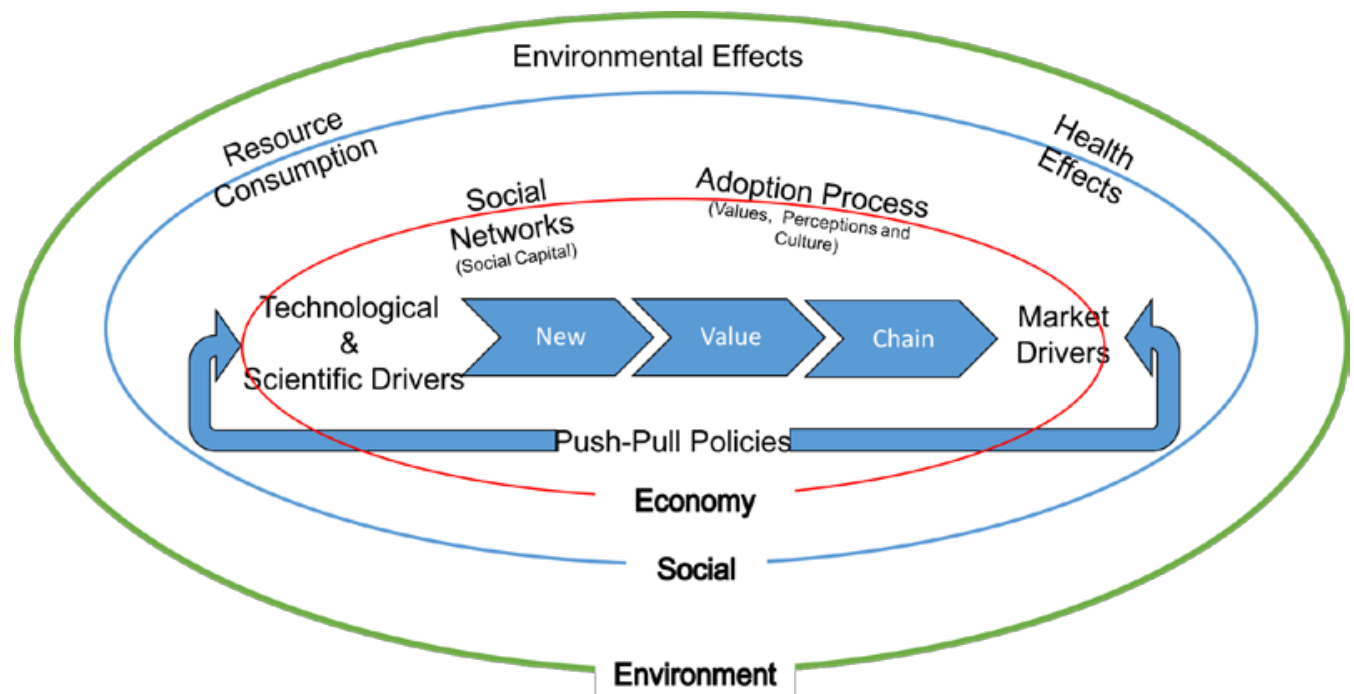

Fig. 2 Suggested conceptual framework for the sustainable development of innovative value chains for the (re) adoption of underutilized crops

In the discussion, we have also argued that market mechanisms and technological policies should be taken into account at the same time, and we have highlighted the importance of government planning and participation to support the push-pull policies. We have also pointed out the role of social networks and their contribution to overcoming knowledge and organizational barriers, and the importance of fostering social capital to enhance access to knowledge, finance and infrastructure.

The creation and distribution of knowledge is determined not only by a social network but also in relation to the production process (value chain relationships). Using the value chain approach, decisions through the entire production process can be analysed in order to suggest technological changes, identify interests and incentives that underpin the creation of new value chains, and reveal the true beneficiaries of the course of action.

Consideration of the life cycle perspective can provide a basis for better decisions to sustain the resource base on which farmers depend. Moreover, considering that the underutilized crops might be not indigenous to the area in which cultivation is planned, attention must be paid to values, perceptions and culture, as they play a decisive role in the process of (re)adoption.

We argue that a more holistic approach will enhance management of the contextual constraints, in order to turn them into opportunities for more sustainable use of new food value chains for (re)adopting underutilized crops. The broad integrative character 
of the framework and its inclusion of contextual circumstances of importance for (re)adoption of underutilized crops make it well suited for comparative studies.

\section{Conclusion}

Research in the past decade into implementation of food policies proposed by European and international organizations with regard to underutilized crops demonstrates the lack of a more holistic model to study the relevant constraints on a faster and more sustainable (re)adoption of underutilized crops.

The studies and literature reviewed have focused on the adoption in developing countries, while studying and reporting on adoption of underutilized crops in EU countries is rare.

Especially when considering the three pillars of sustainability and the literature in the field, there are key constraints that have to be taken into account simultaneously in order to achieve faster and more effective (re)adoption of underutilized crops. These are constraints in the value chain, in the social network, in the adoption process, the existence of push-pull policies, and the environmental impacts (health and resource consumption).

This study suggests a new framework based on the literature reviewed and theoretical discussion. The framework draws on elements from the value chain, social networks, diffusion of innovation, life cycle perspective and drivers of innovation theories, and is thus suitable for a holistic analysis. In presenting this framework, we aim to contribute a more direct and sustainable way to study and influence the (re)adoption process of innovative food crops to foster sustainable value chains, including in the EU.

The model can be used to provide more nuanced explanations of the conditions necessary to overcome constraints or speed up the rate of adoption, in order to implement similar innovations, thus facilitating extrapolation of results.

The model of the framework for the sustainable development of innovative value chains for (re)adoption of underutilized crops is not limited to use for underutilized crops; it could be used for other value chains in the food sector promoted by international policies. The model could also be used to study the adoption of other production processes recommended by European and international organizations aiming to enhance sustainability.

\section{References}

ACP. (2012, january). nuscommunity.org. Retrieved May 30, 2017, from http://www.nuscommunity.org/fileadmin/templates/nuscommunity.org/upload/documents/Ca pacity_and_value_chains_project/EU-ACP_NUS_II_Project_document.pdf

Allen, T., Prosperi, P., Cogill, B., \& Flichman, G. (2014). Agricultural Biodiversity, Social-ecological Systems and Sustainable Diets. Joint Meeting between the Belgian Nutrition Society, The Nutrition Society and Socie té Française de Nutrition, 73, pp. 498-508.

Andersen, P. D., Borup, M., \& Olsen, M. H. (2006, November). Innovation in Energy Technologies. (H. Larsen, L. S. Petersen, \& R. N. Laboratory, Eds.) Riso Energy Report 5, pp. 21-27.

Baldermann, S., Blagojevic, L., Frede, K., Klopsch, R., Neugart, S., Neuman, S., . . . Schreiner, M. (2016, JUN 30). Are Neglected Plants the Food for the Future? Critical Reviews in Plant Sciences, 35(2), 106119. 
Bellon, M. R., Gotor, E., \& Caracciolo, F. (2015, June). Assessing the Effectiveness of Projects Supporting On-Farm Conservation of Native Crops: Evidence From the High Andes of South America. World development, 70, 162-176.

Bhullar, G., \& Bullar, N. (2013). Agricultural Sustainability -Progress and Prospects in Crop Research. (Esevier, Ed.) Zurich, Switerland: Swiss Federal Institute of Technology.

Bjarklev, A., 2012 "An Eco-Design and Innovation Feasibility Study of Low-Carbon

Illumination Technologies for the Tertiary Sector in Denmark" Department of

Environmental, Social and Spatial Changes, Roskilde University, Denmark Ph.D. Thesis.

Bonnar, A. (2014, November 25). Food Navigator. Retrieved March 13, 2017, from http://www.foodnavigator.com

Brundtland, G. (1987). World Commission on Environment and Development:Our Common Future. Environmental Conservation. Cambridge University Press.

Brussaard, L., Caron, P., Campbell, B., Mainka, S., Rabbinge, R., Babin, D., \& Pulleman, M. (2010, May). Reconciling biodiversity conservation and food security: scientific challenges for a new agriculture. Current Opinion in Environmental Sustainability, 2(1-2), 34-42.

Ceccarelli, S., Galie, A., \& Grando, S. (2013). Participatory Breeding for Climate Change-Related Traits. In Genomics and Breeding for Climate- Resilient Crops (Vol. Vol. 1 Concepts and Strategies, p. 517). London: Springer.

Chittarajan , K. (2013). Genomics and Breeding for Climate-Resiliant Crops (Vol. 1 Concepts and Strategies ed.). Springer.

Christinck, A., \& Padmanabhan, M. (2013). Culivate Diversity- a Handbook on Transdiciplinary Approaches to Agrobiodiversity Research. Margraf Publishers.

Cleff, T., \& Rennings, K. (2000). Determinants of Environmental Product and Process Innovation Evidence from the Mannheim Innovation Panel and a Follow-Up Telephone Survey. InnovationOriented Environmental Regulation, 10, 331-347.

Coleman, J. (1988). Social Capital in the Creation of Human Capital. American Journal of Sociology, 94(S1), 95120.

Cork, A., Dobson, H., Grzywacz, D., \& Hodges, R. (2009). Review of pre- and post-harvest pest management for pulses with special reference to East and Southern Africa. University of Greenwich, Natural resources Institute.

Crawford, E. (2015, January 21). Foodnavigator-usa.com. Retrieved March 17, 2017, from http://www.foodnavigator-usa.com/Markets/Sales-of-gluten-free-products-will-continue-togrow-double-digits

de Viseer, C., Schreuder, R., \& Stoddard, F. (2014, July.august). The Eu's dependency on soya bean import for the animal feed industry and potential for EU produced alternatives. OCL, 21(4), 8.

Drzewiecki, J., Delgado-lincon, E., Haruenkit, R., Marin-Belloso, O., Park, Y., Jung, S., . . G Gorinstein, S. (2003, Dec 17). Identification and Differences of total Proteins and their soluble fractions in some Pseudocereals based on Electrophoretic Paterns. J. Adri. Food Chem., 51(26), 7798- 7804.

Durst , P., \& Bayasgalandbat, N. (2014). Promotion of Undertilized Indigenous Food Resources for Food Security and Nutrition in Asia and the pacific. FAO. FAO.

Durst, p., \& Bayasgalanbat, N. (2014). Promotion of Underutilized Indigenous Food Resourses for Food security and Nutrition In Asia and the Pacific. FAO, Regional office for Asia and the Pacific. Bangkok: FAO.

Ebert, A. (2014, November 21). Potential of Underutilized Traditional Vegetables and Legume Crops to Contribute to Food and Nutritional Security, Income and More Sustainable Production Systems. Sustainability, 6(1), 319-335.

Escobedo-López, D., Núñez-Colín, C., \& Espitia-Rangel, E. (2014). Adaptation of Cultivated Amaranth (Amaranthus spp.) and Their Wild Relatives in Mexico. Journal of Crop Improvement, N/a, 203-213.

European Commission. (2013, December). Overview of CAP Reform 2014-2020. Agricultural Policy Perspectives Brief, 5, 10.

European Commission. (2015, June 19). Towards a long-term strategy for European agricultural research and innovation by 2020 and beyond. Background paper, EU pavilion at Expo Milan. Milano.

European Environment Agency. (2015, Junio 30). Agriculture and Clima Change. Signals - Living in a changing climate, p. 11. 
Fanzo, J., Hunter, D., Borelli, T., \& Mattei, F. (2013). Diversifying Food and Diets- Using Agricultural Biodeversity to Improve Nutrition and Health. Routledge.

FAO. (2009). How to Feed the World in 2050. Proceedings of the Expert Meeting on How to Feed the World in 2050. Rome: FAO.

Fasoyiro, S., \& Taiwo, K. (2012). Strategies for Increasing Food Production and Food Security in Nigeria. Journal of Food and Agricultural Information, 338355.

Fearne, A. (2009). Sustainable Food and Wine Value Chains. Adelaide Thinker in Residence, Department of the Primier and Cabinate. Adelide: Goverment of South Australia.

Ferguson, J. (2015). Permaculture As Farming Practice And International Grassroots Network: A Multidisciplinary Study (Doctoral Disertation). University of Illinois at Urbana-Champaign, Urbana.

Feuer, N., \& Garb, Y. (2006). The lock-in of major standard crops and the prospects of underutilized alternative species: A technological systems and institutional analysis. Arava Institute for Environmental Studies, 1-21.

Forster, D., Adamtey, N., Messmer, M., Pfiffner, L., Baker, B., Huber, B., \& Niggli, U. (2012). Organic Agriculture-Driving Innovations in Crop Research. In Agricultural Sustainability-Progress and Prospects in Crop Research (pp. 21-46). Elsevier.

Gereffi, G., \& Kaplinsky, R. (2001). Globalization, Value chains and Development. IDS, 32(3), pp. 1-8.

Gibson, R. B. (2001). Specification of Sustainability-based Environmental Assessment Decision Criteria and Implications for determining "Significance" in Environmental Assessment. Canadian Environmental Agency. Goverment of canada.

Gillman, S. (2017, may 02). How ancient crops could counteract climate change effects. (E. Commission, Producer) Retrieved Octuber 23, 2017, from Horizon, The EU Reasearch \&Innovation Magazine: https://horizon-magazine.eu/article/how-ancient-crops-could-counteract-climate-changeeffects_en.html

Giulani, E., Pirtrobelli, C., \& Rabelloti, R. (2005). Upgrading in Global Value Chains: Lessons from Latin American Clusters. World Development, 33(4), 549-573.

Gonzalves, J. (2013). A new relevance and better prospects for wider uptake of social learning within the CGLAR. CGIAR Research Program on Climate Change, Agriculture and Food Security (CCAFS). CGIAR.

Gorinstein, S., Delgado-Lincon, E., Pawelzik, E., Permady, H., Weiz, M., \& Trakthtenberg, S. (2001). Characterization of soluble Amaranth and Soy Bean Proteins Based on Flourescence, Hidorpphobicity, Electrphoresis, Amino Acid Analysis, Circular Dichroism, and Differential Scanning Calorimetry Measurements. J.Agric.Food Chem.(49), 5595-5601.

Hanson, K. (2016). Contemporary Regional Development in Africa. NY, NY, USA: Routlege.

Hausling, M. (2011). The EU Protein Deficit: Whta Solution for a Long-standing Problem? (E. Parlament, Editor) Retrieved $01 \quad 17, \quad 2017, \quad$ from $\quad$ europarl.europa.eu: http://www.europarl.europa.eu/sides/getDoc.do?pubRef $=-$ //EP//NONSGML+REPORT+A7-2011-0026+0+DOC+PDF+V0//EN

Hawkes, C., Turner, R., \& Waage, J. (2012). Current and Planed Research on Agriculture for Improved Nutrition: a maping and Gap Analysis. A report for DFID, Centre for Sustainable Development.

Herforth, A. W. (2010, May). PROMOTION OF TRADITIONAL AFRICAN VEGETABLES IN KENYA AND TANZANIA: A CASE STUDY OF AN INTERVENTION REPRESENTING EMERGING IMPERATIVES IN GLOBAL NUTRITION.

Hewet, E. (2012, May 31). High-value horticulture in developing countries: barriers and opportunities. Plant Sciences Review, 212-246.

Hilger, T., Lewandoski, I., Winker, B., Ramsperger, B., Kageyama, P., \& Colombo, C. (2015). Seeds of Change - Plant genetic Resources and Peoples's Livelihoods.

Howard, B. C. (2013, August 12). Amaranth: Another Ancient Wonder Food; But Who Will Eat it? Retrieved 03 17, 2017, from Nationalgeographic.com: http://www.nationalgeographic.com/search/?proxystylesheet=site_search\&output=xml_no_dtd $\&$ site $=$ site_search\&start $=0 \& c$ lient $=$ site_search\&getfields $=\% 2$ A\&requiredfields $=$ description\&q $=$ Amaranth $\% 253 \mathrm{~A} \% 20$ Another $\% 20$ Ancient $\% 20$ Wonder $\% 20$ Food $\% 252 \mathrm{CC} \% 20 \mathrm{But} \% 20$ Who $\% 20$ Will $\% 20$ Eat $\% 20 \mathrm{It} \% 253 \mathrm{~F} \&$

Hrideek, T., \& Nsmpoothiri, K. (2016). Millets as an integral Part of Nutritional Diet in India. In B. Sailas, Examining the Development Regulation, and Consumption of Functional Foods (p. 344). IGI Global. 
Ingram, J. (2011, November 24). A food system Approach to Researching Food sSecurity and its Interactions with Global Environmental Chalenge. Food Security, 3(4), 417-431.

Irungu, C., Mburu, J., \& Maundu, P. (2007). Analysis of mMarkets for African Leafy Vegetables Within Nairobi and its Environs and Implications for on- farm Conservation of Biodiversity. Global Facilitation Unit for Underutilized Species (GFU), Rom.

Jacobsen, S.-E., Sørensen, M., Pedersen, S., \& Weiner, J. (2013, March 19). Feeding the World: Genetically Modified Crops Versus Agricultural Biodiversity. Agronomy for Sustainable Development, 33(4).

Jacobsen, S.-E., Sørensen, M., Pedersen, S., \& Weiner, J. (2015, October). Using our agrobiodiversity: plantbased solutions to feed the world. Agronomy for Sustainable Development, 35(4), 1217-1235.

Jones, K. (2014, May). etda.libraries.psu.edu. Retrieved May 30, 2017, from etda.libraries.psu.edu/files/final_submissions/9509:

https://etda.libraries.psu.edu/files/final_submissions/9509

Kahane, R., Hodgking, T., Jaenicke, H., Coosje , H., Herman, M., \& et al. (2013, April 18). Agrobiodiversity for Food Security, Health and Income. Agronomy for Sustainable development, 33(4), pp. 671-693.

Keatinge, J., Wang, J.-F., Dinssa, F., Ebert, A., Hughes, J., Stoilova, T., . . . Ravishankar, M. (2015). Indigenous vegetables worldwide: their importance and future development. XXIX IHC - Proc. I Int. Symp. on Indigenous Vegetables. ISHS.

Kivimaa, P. (2008). The determinants of environmental innovation: The impacts of environmental policies on the Nordic pulp. Helsinki School of Economics. Helsinki School of Economics.

Kjær, A. (2011). Rodhes' Contribution to Governance Theory: Praise, Critisim and Future Gobernance Debate. Public Administration, 89(1), 101-113.

Kline, S. J., \& Rosenberg, N. (1986). An Overview of Innovation. In S. J. Kline, N. Rosenberg, R. Landau, \& N. Rosenberg (Eds.), The Positive Sum Strategy: Harnessing Technology for Economic Growth (pp. 275302). Washington D.C.: National Academy press.

Leakey, R., Tchoungdjeu, Z., Schreckenberg, K., Simons, T., Shacklenton, S., Mnader, M., . . Sullivan, C. (2006). Trees and Markets for Agroforestry Tree Products: Targeting 11 Poverty Reduction and Enhanced livelihoods. In D. Garrity, A. Okono, M. Grayson, \& S. Parrot, World Agroforestry Into the Future (pp. 11-42). World Agroforestry Centre.

Leanne, D. (2014). Food Security in the Kullu District, India: Perspectives, Policies and Learning in the Transition to Commercial Agriculture. Canada: University of manitoba.

Lin, B. (2011, March 1). Resilience in Agriculture through Crop Diversification: Adaptive Management for Environmental Change. BioScience, 61(3), pp. 183-193.

Linton, J. D., Klassen, R., \& Jayaraman, V. (2007, January 17). Sustainable Supply Chains: An Introduction. Journal of Operations Management, 25(2007), 1075-1082.

Maggio, A., Van Criekinge, T., \& Malingreau, J. (2016). Global Food Security 2030 - Assessing trends with a view to guiding future EU policies. JRC, Science and Policy Reports. Brussels: Joint Research Ceneter.

Mal, B., Paludosi, S., \& Bala Ravi, S. (2010). Minor Millets in South Asia: Learnings from IFAD-NUS Project in India and Nepal. Bioversity International, Maccarese, Rome, Italy and the M.S. Swaminathan Research Foundation, Chennai, India., Rome.

Marone, P. A., Birkenbach, V. L., \& Hayes, A. W. (2016, December 09). Newer Approaches to Identify Potential Untoward Effects in Functional Foods. Internal Journal of Toxicology, 35(2), 186-207.

Matson, p., Parton, W., Power, A., \& Swift, M. (1997, July 25). Agricultural Intesification and Ecosystem Properties. SCIENCE, 227(5325), pp. 504-509.

Monge, M., Hartwich, F., \& Halgin, D. (2008, N/a N/a). How change agents and social capital influence the adoption of innovations among small farmers -Evidence from social networks in rural Bolivia. IFPRI. IFPRI. Retrieved March 13, 2017, from http://www.ifpri.org: http://www.ifpri.org/publication/how-changeagents-and-social-capital-influence-adoption-innovations-among-small-farmers

Mwamba, C. (2006). Monkey Orange- Strychos Cocculoides. (J. Williams, R. Smith, N. Haq, \& Z. Dunsiger, Eds.) Southhampton Centre for Underutilised Crops.

Navigator, F. (2013, August 13). Foodnavigator-usa.com. Retrieved March 13, 2017, from foodnavigatorusa.com

Ndegwa, R. (2016, June). Socio-economic factors influencing smallholder pumpkin production, consumption and marketing in eastern and central kenya regions. Retrieved May 30, 2017, from etd-library.ku.ac.ke: http://etdlibrary.ku.ac.ke/bitstream/handle/123456789/14958/Socio- 
economic $\% 20$ factors $\% 20$ influencing $\% 20$ smallholder $\% 20$ pumpkin........pdf?sequence $=1$ \&isAllowe $\mathrm{d}=\mathrm{y}$

Nemet, G. F. (2009, June). Demand-pull, technology-push, and government-led incentives for nonincremental technical change. Research Policy, 38(5).

Nuijten, E., Messmer, M., \& Lammerts van Bueren, E. (2017). Concepts and Strategies of Organic Plant Breeding in Light of Novel Breeding Techniques. (G. U. Ryffel, Ed.) Sustainability, 9(1), 1-19.

Oladele, O. (2013). Linkage between Gown and Town: My experience in Sub-Sabaran Africa and South East Asia. Lecture, North West University Mafikeng .

Onyango, A. M. (2010). African Indigenous Vegetables In Kenya: Strategic Repositioning in the Horticultural Sector.

Onyema, M., Osuagwu, N., \& Ekpenyong, S. (2013). An Application of SWOT Analysis in Development of Underutilized Plant Species in a Rural Hot Spur in Africa. International Journal of Science and Research (IJSR).

Padulosi, S., Amaya, K., Jäger, M., Gotor, E., Rojas, W., \& Valdivia, R. (2014). A Holistic Aproach to Enhance the Use of Negelcted and Underutilized Spicies. Sustainability, 6(3), pp. 1283-1312.

Paludosi, S., Hodgkin, T., \& Haq, N. (2002). Underutilized Crops: Trends, Chalenges and Opportunities. In R. Rmantha, A. Brown, \& M. Jackson, Managing Plant Genetic Diversity (p. 489). Wallingford, Oxford, UK: CABI.

Peter, K. (2008). Underutilized and Underexploited Horticultural Crops (Vol. 4). Kerala, India: New India Publishing Agency.

Porter, M. (1985). Competitive Advantage - Creating and Sustaining Suoerior Performance (First Press Edition 1985 ed.). New York, NY, USA: The Free Press.

Putnam, R. (1993). The Prosperous Community - Social Capital and Public life. The american prospect, 4(13), $35-42$.

Ramwar, M., \& Siew, N. (2017). Strategic Approaches to Food Security in Developing Countries. In W. Ganpat, Agricultural Development and Food Security in Developing Nations (p. 198). Hershey, PA., USA: IGI- Global.

Rastogui, A., \& Shukla, S. (2011). Amaranth: A New Millenium Crop of Nutraceutical Values. Critical Reviens in Food Science and Nutrition, N/a, 109-125.

Raviv, M. (2010). Is Organic Horticulture Sustainable? Chronica Horticulturae, 50(2), pp. 7-14.

Rennings, K. (2000, February). Redefining innovation - eco-innovation research and the contribution from ecological economics. Ecological Economics, 32(2), 319-332.

Rogers, E. M. (2003). Diffusion of Innovation (Fith Edition ed.). New York: Free Press.

Rudebjer, P., Chakeredza, S., Dansi, A., Ekaya, W., Ghezae, N., Aboagye, L., . . Padulosi, S. (2011). Beyond Commodity Crops: Strengthening Young Scientist. II International Symposium on Underutilized Plant Species: Crops for the Future - Beyond Food Security. 979, pp. 577-598. ISHS Acta Horticulturae.

Sajise , P., \& Ahmad, I. (2008). Conservation and Sustainable use of Tropical and Sub-tropical Fruits: current status and prospects. 787, 97-112. Acta Hortic.

Saliola, F., \& Zanfei, A. (2009). Multinational firms, global value chains and the organization of knowledge transfer. Research Policy, 38, 369-381.

Sharma, S., \& Wightman, J. (2015). Vision Infinity for Food Security. Springer Link.

Shumsky, S., Hickey, G. M., Johns, T., Palletier, B., \& Galaty, J. (2014, May). Institutional Factors Affecting Wild Edible Plant (WEP) Harvest and Consumption in Semi-arid Kenia. Land Use Policy, 38, 48-69.

Stamp, P., Messmer, R., \& Walter, A. (2012, August). Competitive underutilized crops will depend on the state funding of breeding programmes:an option on the example of Europe. Plant Breeding, 131(4), 461-464.

Sthapit, B., \& Gauchan, D. (2006). On-farm Management of Agricultural Biodiversity in Nepal- lessons Learned. Proceedings of National Symposium, 18-19 JULY 2006, Kathmandu, Nepal.

Svendsen, G. L. (2001, 01). Hvad er Social Kapital. Dansk Socilogi, 12(01), pp. 50-61.

Turok, e. a. (2001, August). Global effort in support of neglected and underutilized species . PPGRI newslatter for Europe, 21.

UNDP. (2012). Institutional and Context Analysis. United Nations Development Programme, Democratic Governance. Oslo Governace Centre.

UNEP - UNCTAD. (2008). Organic Agriculture and Food Security in Africa. United nations Conference on trade and Development -United nations Environment Programmme (p. 47). New York: UNCTAD. 
UNEP. (2011). Towards a Green Economy: Pathways to Sustainable Development and Poverty Eradication,. UNEP. UNEP.

United Nations. (2015). Sustainable Development Goals. (UN, Producer) Retrieved November 24, 2017, from http://www.un.org/sustainabledevelopment/sustainable-development-goals/: http://www.un.org/sustainabledevelopment/sustainable-development-goals/

Vargas Vallejos, R., Macke, J., \& Toss, E. (2008). Collaborative Networks and Social Capital: a Theoretical and Practical Convergence. Working Conference on Virtual Enterprices. 283, pp. 43-52. Boston, MA: Springer, .

Vernooy, R., Jingsong, L., \& Li, Z. (2008, March). The Impact of National, Regional and Global Agricultural Policies and Agreements on Conservation and Use of Plant Genetic Resources for Food and Agriculture. Retrieved May 09, 2017, from fao.org: http://www.fao.org/fileadmin/templates/agphome/documents/PGR/SoW2/PGR_Policy_The matic_Study.pdf

Watson, B. (2008). How to Assist the Small-Scale Farmer. International Assessmet of Agricultural and Technology for Development. Retrieved from http://www.un.org/en/ecosoc/docs/statement08/robert_watson.pdf.

Williams, J. T., \& Haq, N. (2002). Global Research on Underutilized Crops-An assessment of current activities and proporsals for enbanced cooperation. Southampton, UK: International center for Underutilzed Crops.

Williams, J., \& Haq, N. (2002). Global Research on Underutilized Crops - An Assessment of Current Activities and Proposals for Enhance Cooperation. southhampton, UK: ICUC.

Wolfenson, K. M. (2013). Coping with the food and agriculture challenge: smallholders' agenda. 2012 United Nations Conference on Sustainable Development (Rio +20). Food and Agriculture Organization of the United Nations.

Wood, L. (2016, April 06). marketwired.com. Retrieved March 13, 2017, from ResearchandMarkets: http://www.marketwired.com/press-release/global-organic-food-beverage-market-analysistrends-growth-forecast-to-2020-2112417

Zhou, L., Wu, W.-p., \& Luo, X. (2007, may 10). Internationalization and the Performance of Born-global SMEs: the mediating role of social medium. Journal of International Bussiness Studies, 38, 673-690. 